Note

\section{Isolation of a New Pyranose Oxidase Producing Basidiomycete}

\author{
Yoshikazu Izumi, ${ }^{*}$ Yuji FuruYA** \\ and Hideaki YAMADA \\ Department of Agricultural Chemistry, \\ Faculty of Agriculture, Kyoto University, \\ Kyoto 606, Japan \\ Received August 23, 1989
}

Pyranose oxidase (PROD) (EC 1.1.3.10) catalyzes the oxidation of D-glucose to $\mathrm{D}$-glucosone with the reduction of molecular oxygen to hydrogen peroxide. This enzyme has been purified and characterized from several basidiomycetes. ${ }^{1-5)}$ It has also been reported that other basidiomycetes had glucose-2-oxidase activity ${ }^{6)}$ and formed D-glucosone. ${ }^{7}$

This enzyme may be used for blood glucose measurement without the addition of mutarotase ${ }^{87}$ and for assaying 1,5-anhydroglucitol, a marker for the diagnosis of diabetes. ${ }^{9}$ Therefore, it is necessary to obtain an organism with a high specific activity of PROD. In this study, we describe the isolation of a new basidiomycete with a high activity of PROD and compare it to the known PRODproducing basidiomycetes mycologically and immunologically.

Screening for PROD-producing microorganisms was done by a modification of the method of Horwath. ${ }^{10}$ We isolated 3 strains with high PROD-producing activity from soil. The best producer among them was designated as basidiomycetous fungus No. 52 (strain No. 52). This strain was used for the following study.

Strain No. 52 was cultured in a medium containing $0.5 \%$ glucose, $0.4 \%$ yeast extract, $1.0 \%$ malt extract, and $0.001 \% \mathrm{FeCl}_{3} \cdot 6 \mathrm{H}_{2} \mathrm{O}(\mathrm{pH} 6.0)$ at $28^{\circ} \mathrm{C}$ for 4 days with shaking. The grown cells were harvested and washed with $50 \mathrm{~mm}$ potassium phosphate buffer $(\mathrm{pH} \mathrm{7.0)}$ and disrupted with sea sand in an agate mortar with a pestle cooled with ice. The supernatant fluid was obtained by centrifugation and used as the crude extract. The procedure used for the assay of PROD activity was based on the method of Allain et al. ${ }^{11)}$ The standard assay mixture contained $33 \mu \mathrm{mol}$ glucose, $0.82 \mu \mathrm{mol} 4$-amino antipyrine, $14 \mu \mathrm{mol}$ phenol, 8 units peroxidase, $50 \mu \mathrm{mol}$ potassium phosphate buffer $(\mathrm{pH}$ 7.0 ), and enzyme in a total volume of $3 \mathrm{ml}$. One unit of enzyme was defined as the amount causing $1 \mu \mathrm{mol}$ of $\mathrm{H}_{2} \mathrm{O}_{2}$ formation from glucose per min at $37^{\circ} \mathrm{C}$ under the stan- dard assay conditions. Protein was measured by the method of Bradford ${ }^{12)}$ with a Bio-Rad standard solution.

To confirm that a D-glucose-oxidizing enzyme from strain No. 52 was PROD, a reaction mixture consisting of $1 \mathrm{ml}$ of $2 \%$ glucose, $0.4 \mathrm{ml}$ of $0.1 \mathrm{M}$ potassium phosphate buffer ( $\mathrm{pH} 7.0), 0.05 \mathrm{ml}$ of 1300 units $/ \mathrm{ml}$ catalase, and $1 \mathrm{ml}$ of crude enzyme in a total volume of $2.5 \mathrm{ml}$ was incubated at $30^{\circ} \mathrm{C}$ overnight, and the enzymatic oxidation product of D-glucose was analyzed by thin layer chromatography (TLC) and high performance liquid chromatography (HPLC). TLC plates (DC Alufolien Kieselgel $60 \mathrm{~F}_{254}$; Merck, G.F.R.) were used.

When the developing solvent of TLC was phenol-water (4:1, by vol), D-glucose and D-glucose gave spots with $R f$ values of 0.18 and 0.25 , respectively. When the developing solvent of butyl acetate-acetic acid-acetone-water (140:100:33:80, by vol) was used, D-glucosone and Dglucose gave spots of $R f$ values of 0.15 and 0.18 , respectively. The oxidation product of D-glucose obtained with PROD had the same mobility on TLC as authentic Dglucosone. With the diphenylamine-aniline-phosphoric acid-ethyl acetate $(0.15 \mathrm{~g} / 0.8 \mathrm{ml} / 11 \mathrm{ml} / 100 \mathrm{ml})$ reagent, the glucose oxidation product by $\mathrm{PROD}$ and D-glucosone gave a purple spot, while D-glucose gave a brown spot.

The enzymatic oxidation product of D-glucose was also identified by HPLC with a refractive index detector and a Shodex Sugar SP1010 column (Showa Denko Co., Japan). Analysis conditions of HPLC were as follows: the mobile phase was water. The flow rate and column temperature were set at $1.0 \mathrm{ml} / \mathrm{min}$ and at $80^{\circ} \mathrm{C}$. As a result, the retention time of authentic D-glucosone was the same as that of the glucose oxidation product by PROD.

Next, we examined the taxonomy of strain No. 52. After the strain was cultivated on artificial (yeast-malt extract agar or potato-dextrose agar) or natural media (wood, straw, or cereals) at $25^{\circ} \mathrm{C}$ for several days, we observed the shape of hyphae and fruit body formation on the media.

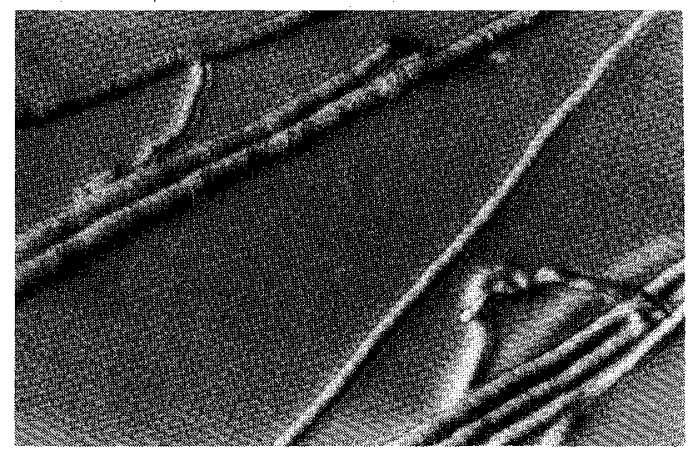

Fig. 1. Photomicrograph of Strain No. 52. The bar length is $20 \mu \mathrm{m}$.

* Present address: Department of Biotechnology, Faculty of Engineering, Tottori University, Tottori 680, Japan.

** Present address: Research Laboratory, Ikeda Toka Kogyo Co., Fukuyama, Hiroshima 721, Japan. 
Table I. Comparison of Basidiomycetous Fungus No. 52 with Various Basidiomycetes in Mycological Properties and PROD Activities

\begin{tabular}{|c|c|c|c|c|c|c|}
\hline & \multirow[b]{2}{*}{ Organism } & \multicolumn{3}{|c|}{ Mycological properties } & \multicolumn{2}{|c|}{ PROD activity $^{d}$} \\
\hline & & $\begin{array}{c}\text { Clampa } \\
\text { connection }\end{array}$ & $\begin{array}{l}\text { Laccase }^{b} \\
\text { reaction }\end{array}$ & Growth ${ }^{c}$ & $\begin{array}{c}\text { Specific } \\
\text { activity } \\
\text { (units/mg) }\end{array}$ & $\begin{array}{c}\text { Cultivation } \\
\text { (days) }\end{array}$ \\
\hline 1. & Basidiomycetous fungus No. 52 & - & \pm & ++ & 0.81 & 4 \\
\hline 2. & Coriolus versicolor IFO 4937 & + & +++ & ++ & 0.63 & 4 \\
\hline 3. & Daedaleopsis styracina IFO 4910 & + & +++ & ++ & N.D. ${ }^{e}$ & 4 \\
\hline 4. & Trametes cinnabarinus IFO 6139 & + & $++t$ & ++ & 0.011 & 4 \\
\hline 5. & Auricularia polytrica IFO 30778 & - & ++ & - & 0.19 & 4 \\
\hline 6. & Gloeophyllum sepiarium NRRL 12506 & + & - & \pm & 0.22 & 10 \\
\hline 7. & Pleurotus ostreatus NRRL 12507 & + & $+t$ & - & N.D. & 4 \\
\hline 8. & Coprinus micaceus ATCC 20122 & - & + & - & N.D. & 4 \\
\hline 9. & Irpex lacteus ATCC 20123 & - & ++ & - & 0.14 & 4 \\
\hline 10. & Polyporus obtusus ATCC 26733 & + & ++ & - & 0.12 & 5 \\
\hline
\end{tabular}

a Clamp connection: The basidiomycetes were cultured on a medium containing $2 \%$ malt extract, $2 \%$ glucose, $0.1 \%$ Polypepton, and $2 \%$ agar at $28^{\circ} \mathrm{C}$ for several days. + , formed; - , not formed.

$b$ Laccase reaction: The cultures were grown on the above malt extract agar medium containing $0.5 \%$ tannic acid at $28^{\circ} \mathrm{C}$ for several days. - negative; \pm , quasi positive; + , positive (discoloration diameter was in the range of $0.1-1.0 \mathrm{~cm}$ ); ++ , positive (discoloration diameter was in the range of $1.0-3.0 \mathrm{~cm}$ ); +++ , positive (discoloration diameter was more than $3.0 \mathrm{~cm}$ ).

c Growth: Cultivation was done on the medium as described in the laccase reaction: -, no growth; \pm , slight growth; + , growth diameter was in the range of $0.1-1.0 \mathrm{~cm} ;++$, growth diameter was in the range of $1.0-$ $3.0 \mathrm{~cm}$.

¿ PROD activity: The basidiomycetes except for Polyporus obtusus were cultured in the same medium as that of strain No. 52. Polyporus obtusus was cultured in a medium containing $2 \%$ glucose, $0.3 \%$ yeast extract, $1 \%$ Polypepton, $0.3 \% \mathrm{KH}_{2} \mathrm{PO}_{4}$, and $0.1 \% \mathrm{MgSO}_{4} \cdot 7 \mathrm{H}_{2} \mathrm{O}$ for 5 days at $28^{\circ} \mathrm{C}$ with shaking.

e Not detected.

The strain was never found to sporulate and the hypae grew in a woolly shape on the agar surface, and had no characteristic wall thickening, no clamps, and no special branching pattern. A photomicrograph of the strain is shown in Fig. 1. When growth on $5 \%$ benomyl agar medium by the method of Maloy ${ }^{13\}}$ was examined, strain No. 52 grew well on potato-dextrose agar medium with or without benomyl. Although benomyl resistance is not a taxonomical key for basidiomycetes, it is known as a significant characteristic of wood decay fungi or basidiomycetes. ${ }^{13)}$ Therefore, from these morphological and physiological characteristics, strain No. 52 was classified as a basidiomycete.

This strain was compaired to the known PRODproducing ones, as indicated in Table $I$, in terms of mycological and immunological properties.

First it was investigated whether or not other known PROD-producing strains had clamp connections. As shown in Table I, since the hyphae of strain No. 52 had no clamps, the strain was entirely different from Coriolus versicolor (IFO 4937), Daedaleopsis styracina (IFO 4910), Trametes cinnabarinus (IFO, 6139), Gloeophyllum sepiarium (NRRL 12506), Pleurotus ostreatus (NRRL 12507), and Polyporus obtusus (ATCC 26733), which all have clamp connections.

The laccase reaction and ability to grow on malt extract agar medium containing $0.5 \%$ tannic acid were examined. Strain No. 52 had a faint laccase reaction and moderate growth on this medium, while Auricularia polytrica (IFO 30778) and Irpex lacteus (ATCC 20123) had dark brown areas derived from intense laccase reactions and did not grow on this medium. Similarly Coprinus micaceus (ATCC 20122) did not grow on malt extract agar medium containing $0.5 \%$ tannic acid. Therefore, it was confirmed that strain No. 52 differed from these three basidiomycetes.

Secondly, immunodiffusion techniques by the method of Ouchterlony ${ }^{14)}$ were used to test for the ability of antiserum prepared against the purified PROD of strain No. 52 to form precipitin lines with the enzymes from the known PROD-producing basidiomycetes and commercial enzymes. A precipitin line was not formed with cell-free extracts from PROD-producing basidiomycetes except Irpex lacteus. When a cell-free extract of Irpex lacteus and the purified PROD of strain No. 52 were placed in neighboring wells, cross-reaction was observed, but the precipitin was very faint (Fig. 2). These results indicated that strain No. 52 was different from the known PRODproducing basidiomycetes. 

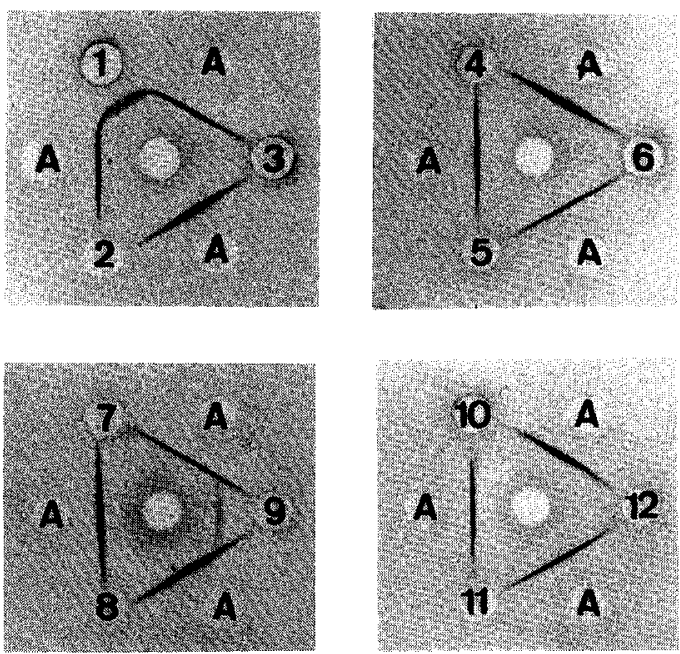

Fig. 2. Double-immunodiffusion Analysis of PROD from Several Basidiomycetes and Two Commercial Enzymes.

The central well contained antiserum $(10 \mu \mathrm{l})$ against the purified enzyme of basidiomycetous fungus No. 52. Contents of the peripheral wells were as follows: A, the purified PROD from strain No. 52 (0.1 unit); I to 10 , crude extracts of PROD from the following strains: 1, strain No. 52 (0.05 unit); 2, Coriolus versicolor (0.05 unit); 3, Daedaleopsis styracina (10-fold concentrated crude enzyme); 4, Trametes cinnabarinus (0.0I unit); 5, Auricularia polytrica $(0.02$ unit); 6, Gloeophyllum sepiarium $(0.03$ unit); 7, Pleurotus ostreatus (10-fold concentrated crude enzyme); 8, Coprinus micaceus (10-fold concentrated crude enzyme); 9, Irpex lacteus (0.02 unit); 10, Polyporus obtusus (0.05 unit); 11, commercial enzyme from Takara Shuzo Co. (derived from Polyporus oblusus) (0.04 unit); 12, commercial enzyme from Kyowa Hakko Co. (derived from Coriolus versicolor) (0.04 unit).
Thus, we concluded that strain No. 52 was a new PROD-producing strain

From the comparison of the enzymatic characterization described elsewhere, we also confirmed the above fact because the purified PROD of strain No. 52 differed from those of Polyporus, ${ }^{2)}$ Coriolus $^{41}$ and Phanerochaete. ${ }^{5)}$

Acknowledgment. We wish to express our thanks to Dr. J. Okuda of Meijo University for the supply of Dglucosone.

\section{References}

1) H. W. Ruelius, R. M. Kerwin and F. W. Janssen, Biochim. Biophys. Acta, 167, 493 (1968).

2) F. W. Janssen and H. W. Ruelius, Biochim. Biophys. Acta, 167, 501 (1968).

3) F. W. Janssen and H. W. Ruelius, "Methods in Enzymology," Vol. XLI, ed. by W. A. Wood, Academic Press Inc., New York, 1975, p. 170.

4) Y. Machida and T. Nakanishi, Agric. Biol. Chem., 48, 2463 (1984).

5) K. E. Eriksson, B. Pettersson, J. Volc and V. Musilek, Appl. Microbiol. Biotechnol., 23, 257 (1986).

6) J. Volc, P. Sedmera and V. Musilek, Folia Microbiol., 23, 292 (1978)

7) M.-A. Baute, R. Baute, G. Deffieux and M.-J. Filleau, Phytochemistry, 16, 1895 (1977).

8) T. Taguchi, K. Ohwaki and J. Okuda, J. Appl. Biochem., 7, 289 (1985).

9) T. Nakamura, M. Yabuuchi, K. Kato, M. Masuda and H. Akanuma, Eur. Patent 261,591 (Mar. 30, 1988).

10) R. O. Horwath, U. S. Patent $4,568,638$ (Feb. 4, 1986).

11) C. C. Allain, L. S. Poon, C. S. G. Chan, W. Richmond and P. C. Fu, Clin. Chem., 20, 470 (1974).

12) M. Bradford, Anal. Biochem., 72, 248 (1976).

13) O. C. Maloy, Plant Dis. Reptr., 58, 10 (1974).

14) O. Ouchterlony, Acta Pathol. Microbiol. Scand., 32 , 231 (1953). 